\title{
Application of headspace for research volatile organic compounds emitted from building materials
}

\author{
Beata Kultys ${ }^{1, *}$, Karolina Waląg ${ }^{1}$ \\ ${ }^{1}$ Jagiellonian University in Krakow, Faculty of Chemistry, Gronostajowa 2, 30-387 Krakow, Poland
}

\begin{abstract}
Headspace technique and gas chromatography method with mas detector has been used for the determination of volatile organic compounds (VOC) emitted from various building and finishing materials, such as sealing foams, mounting strips, paints, varnishes, floor coverings. The tests were carried out for different temperatures (in the temperature range of 60 to $180{ }^{\circ} \mathrm{C}$ ) and the time of heated vials with tested materials inside. These tests were conducted to verify the possibility of use this method of determination the VOC emission. Interpretation of chromatograms and mass spectra allowed to identify the type of compounds emitted from the tested materials and the optimum time and temperature for each type of material was determined. The increase in heating temperature of the samples resulted in increase the type and number of identified compounds: for four materials the increase was in the whole temperature range, for others it was from $90{ }^{\circ} \mathrm{C}$. On the other hand, emission from mineral wool was low in whole temperature range. 30-minutes heating of the samples was sufficient to identify emitted compounds for most of tested materials. Applying a longer time, i.e. 24 hours, significantly increased the sensitivity of the method.
\end{abstract}

\section{Introduction}

Volatile organic compounds (VOC) may be one of the factors that may adversely affect indoor air quality and in the extreme case they can lead to symptoms of the so-called "Sick building syndrome". Sources of emissions of these compounds can be both indoor and outdoor [1-4]. Parallel testing of indoor and outdoor air only allows you to statement if the source of the emission is in the test room. But if the research is conducted to improve the quality of indoor air it is necessary to identify the source of the emission. VOC emissions may result from human activities in the room (for example the use of solvents, doing experiments) or may come from the elements of the room, finishing and construction materials. Emissions test from materials are typically carried out in emission chambers at a steady gas flow and humidity [5-9]. They allow to determine the magnitude of emission of test material in order to verify compliance with emission standards, e.g. before

\footnotetext{
${ }^{*}$ Corresponding author: beata.kultys@uj.edu.pl
} 
introduction into usage. VOC emission tests also use thermal desorption, ie the release of volatile compounds from the solid under the influence of heat $[10,11]$.

In this study, the headspace technique was used for examination VOC emissions from construction and finishing materials. Headspace is based on the analysis of the gas phase in equilibrium with the condensed phase [12-15]. That method has many uses, in particular for complex matrix samples, such as environmental and biological samples [14-16]. The gas phase composition was determined by means of a gas chromatograph with a mass detector, this made it possible to identify the compounds emitted from the materials. The research was conducted for building and finishing materials used in the construction of the Faculty of Chemistry of the Jagiellonian University, such as sealing foams, mounting strips, paints, varnishes and floor coverings. The appropriate time and temperature of the material being heated in the vial is essential for the headspace technique to be effective. The paper presents the results of studies on the influence of temperature and time on the type and amount of emitted compounds from tested materials.

\section{Materials and research methods}

In order to determine the type and amount of compounds emitted from materials, a static headspace method was used, in which the gaseous phase in equilibrium with the condensed phase (liquid or solid) is analyzed. In this method, a sample with an analyte content of $C_{S^{0}}$ is placed in a vial (stage I), where the analyte passes to the gas phase according to the partition coefficient $K=C_{S} / C_{G}$ at a set temperature (stage II). The gas phase is taken for chromatographic analysis using a syringe (stage III) or a dosing loop $[12,13]$. The principle of the headspace method is illustrated in Figure 1.

( I)

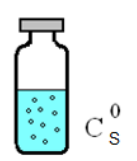

(II)

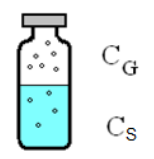

(III)

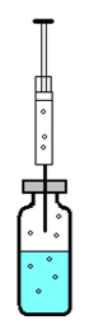

Fig. 1. Stages of headspace technique: (I) - placement of the test material in the vial, (II) establishing the equilibrium, (III) - taking the gas phase for chromatographic analysis.

The basis for calculating the amount of analyte in the headspace method is dependence the concentration of the analytes in the gas and condensed phase from the initial concentration in condensed phase. Mass balance of the system is expressed by the equation:

$$
C_{S}{ }^{0} \cdot V_{S}=C_{G} \cdot V_{G}+C_{S} \cdot V_{S}
$$

where: $C_{S}{ }^{0}-$ is concentration of the analyte in the sample; $V_{S}$ - volume of condensed phase; $C_{G}$ - concentration of the analyte in the gas phase at steady state; $V_{G}$ - volume of the gas phase above the condensed phase; $C_{S}$ - concentration of the analyte in condensed phase at steady state. Calibration is necessary for quantitative determination but in this case, such calibration was not performed because the purpose of the study was merely to identify the type of compounds emitted from the tested materials.

Thirteen types of building and finishing materials were tested. This materials were used during building a new building of the Faculty of Chemistry of the Jagiellonian University at Gronostajowa 2 street. The characteristics of the tested materials, i.e. the commercial name 
Table 1. Characteristics of the tested materials.

\begin{tabular}{|c|c|c|c|c|}
\hline & Trade name & Chemical compozition & $\begin{array}{c}\text { Average } \\
\text { weight }[g]\end{array}$ & Use of building material \\
\hline A & $\begin{array}{l}\text { PVC cable trays } \\
\text { (perforated) }\end{array}$ & polyvinyl chloride & 6.82 & $\begin{array}{l}\text { Designed for carrying } \\
\text { cables, for example in } \\
\text { control cabinets }\end{array}$ \\
\hline B & $\begin{array}{l}\text { corrugated PVC } \\
\text { pipe }\end{array}$ & polyvinyl chloride & 1.63 & $\begin{array}{c}\text { Shielded plastic tube for } \\
\text { electrical cables }\end{array}$ \\
\hline $\mathrm{C}$ & styrofoam EPS & expanded polystyrene & 0.36 & $\begin{array}{l}\text { Designed for thermal } \\
\text { insulation of buildings }\end{array}$ \\
\hline $\mathrm{D}$ & $\begin{array}{l}\text { mineral wool, } \\
\text { on the outside are } \\
\text { covered with } \\
\text { aluminum foil } \\
\text { (CONLIT PLUS } \\
\text { system, Rockwool } \\
\text { producer) }\end{array}$ & $\begin{array}{c}\text { silica } 34-45 \%, \\
\text { alumina } 15-24 \%, \\
\text { iron(III) oxide } 2-1 \%, \\
\text { calcium oxide }+ \text { magnesium } \\
\text { oxide } 20-35 \%, \\
\text { sodium oxide }+ \text { potassium } \\
\text { oxide } 1-7 \% \\
\text { (aluminum foil not included } \\
\text { in the samples tested) [17] }\end{array}$ & 1.77 & $\begin{array}{l}\text { Designed for fire protection } \\
\text { insulation, for example } \\
\text { isolation of ventilation } \\
\text { ducts, air conditioning } \\
\text { ducts and smoke extraction } \\
\text { ducts }\end{array}$ \\
\hline $\mathrm{E}$ & $\begin{array}{l}\text { fireproof } \\
\text { polyurethane } \\
\text { foam }\end{array}$ & polyurethane & 0.75 & $\begin{array}{l}\text { Designed to fill, for } \\
\text { example, the ceiling } \\
\text { contact and the wall in } \\
\text { walls of the fire zone }\end{array}$ \\
\hline $\mathrm{F}$ & $\begin{array}{l}\text { blue styrodur } \\
\text { STYROFOAM } \\
\text { XPS } 300\end{array}$ & extruded polystyrene & 0.62 & $\begin{array}{l}\text { Designed for example for } \\
\text { warming up the floor on the } \\
\text { ground, on the ceiling or as } \\
\text { a foundation warming }\end{array}$ \\
\hline G & $\begin{array}{c}\text { PVC Tarkett iQ } \\
\text { Granit } \\
\end{array}$ & polyvinyl chloride & 11.99 & Used in the corridors \\
\hline $\mathrm{H}$ & $\begin{array}{l}\text { polyurethane } \\
\text { foam }\end{array}$ & polyurethane & 0.85 & Used for insulation \\
\hline I & $\begin{array}{l}\text { dispersion latex } \\
\text { white paint for } \\
\text { interior } \\
\text { (Acryl } 3000 \text { PS } \\
\text { Dekoral } \\
\text { professional) } \\
\end{array}$ & $\begin{array}{c}\text { polymer emulsions, } \\
\text { it also contains: } 5 \text {-chloro- } \\
\text { 2-methyl-2H-isothiazol-3-one } \\
\text { (2-methyl-2H) isothiazol-3- } \\
\text { one (CMIT/MIT) 3: } 1 \text { and } \\
\text { 1,2-benzisothiazol-3(2H)-one }\end{array}$ & 5.45 & $\begin{array}{l}\text { Designed for decorative } \\
\text { painting of walls and } \\
\text { ceilings indoors }\end{array}$ \\
\hline $\mathrm{J}$ & $\begin{array}{l}\text { Ecophon Focus E } \\
\text { - suspended } \\
\text { ceiling (filled with } \\
\text { glass wool, } \\
\text { painted outside) }\end{array}$ & $\begin{array}{c}\text { glass wool: } \\
\text { silicon(IV) oxide } 45-70 \% \text {, } \\
\text { aluminum(III) oxide } 0-7 \% \text {, } \\
\text { iron(III) oxide } 0-5 \%, \\
\text { calcium oxide } 5-13 \% \text {, } \\
\text { magnesium oxide } 0-5 \% \text { [18], } \\
\text { Akutex TM FT coating }\end{array}$ & 1.54 & $\begin{array}{l}\text { Used for example in the } \\
\text { office rooms. It has an } \\
\text { aesthetic function and } \\
\text { above all an acoustic } \\
\text { function }\end{array}$ \\
\hline K & $\begin{array}{c}\text { polyurethane } \\
\text { semi-matt parquet } \\
\text { lacquer (Supramal } \\
303 \text { ) } \\
\end{array}$ & $\begin{array}{c}\text { polyurethane, } \\
\text { it also contains N, N- } \\
\text { dimethylethanolamine }\end{array}$ & 2.53 & $\begin{array}{l}\text { Designed for parquet } \\
\text { flooring }\end{array}$ \\
\hline $\mathrm{L}$ & perforated profile & lack of information & 6.39 & $\begin{array}{c}\text { Many uses, e.g. } \\
\text { reinforcement for structural } \\
\text { elements }\end{array}$ \\
\hline M & gray styrodur XPS & extruded polystyrene & 0.38 & $\begin{array}{l}\text { e.g. for warming up the } \\
\text { floor on the ground, on the } \\
\text { ceiling or as a foundation } \\
\text { warming }\end{array}$ \\
\hline
\end{tabular}


of the material, its main chemical composition and application, and the average mass of the samples, are presented in Table 1. Photographs of the tested materials are shown in Figure 2.
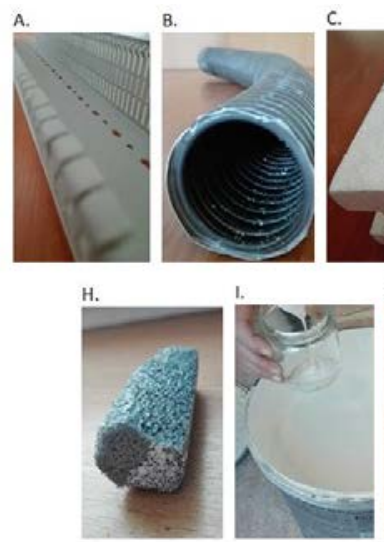
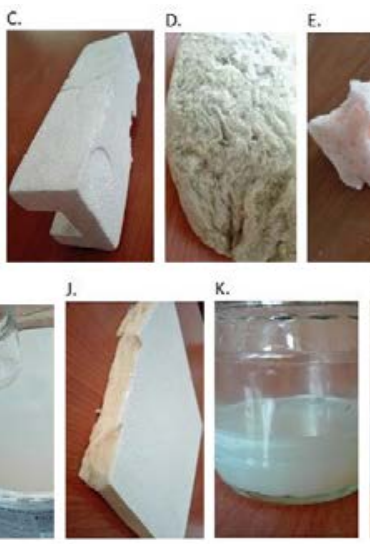
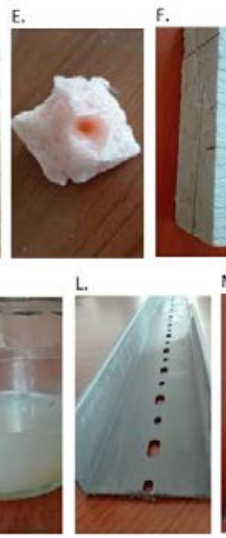
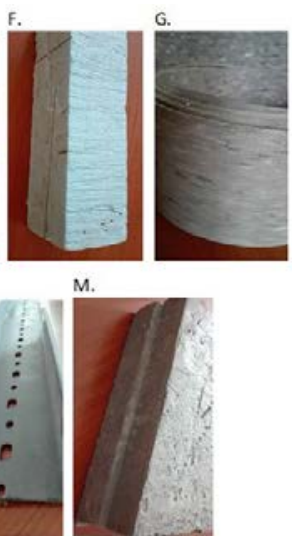

Fig. 2. Photos of the tested materials. Indication of materials according to Table 1.

The preparation of samples for analysis consisted of: excision the right amount of material, placement in the vial, tight vial closure and finally heating the vials with the tested material for a fixed time and at a certain temperature. Samples of material were placed in vials of $20 \mathrm{~cm}^{3}$. In each case, the volume of the condensed phase was half the volume of the vial. Materials were heated at $60,90,120$ and $150{ }^{\circ} \mathrm{C}$. Heating time was 30 minutes, 2 and 24 hours. After heating of the sample, the gas phase was introduce to the gas chromatograph using a loop. Chromatographic analyses were performed by gas chromatograph (HP 6890) coupled to a mass detector (HP 5973). A capillary column with low polarity phase was used (methyl-5\%-phenylsiloxane, film thicknes $0,25 \mathrm{~mm}$ ) with a length of $30 \mathrm{~m}$ and a diameter of $0.25 \mathrm{~mm}$, purchased from J\&W Scientific.

The temperatures of the Headspace-GC transfer line and the injector were $160{ }^{\circ} \mathrm{C}$ and $200{ }^{\circ} \mathrm{C}$, respectively. Helium was used as the carrier gas at a flow rate of $1 \mathrm{~cm}^{3} / \mathrm{min}$ Chromatographic analysis conditions were as follows: the column was initially maintained at $50{ }^{\circ} \mathrm{C}$ for $3 \mathrm{~min}$, then the temperature increased to $200{ }^{\circ} \mathrm{C}$ at a rate of $15^{\circ} \mathrm{C} / \mathrm{min}$, which then was held for $10 \mathrm{~min}$.

The analytes after separation in the chromatographic column were directed into mass detectors where the compounds were ionized with an electron beam of energy $70 \mathrm{eV}$ and ions were separated in quadrupole. The MS was operated in the SCAN mode with the $\mathrm{m} / \mathrm{z}$ range of $30-250 \mathrm{amu}$. The temperature of ion source and quadrupole was $230{ }^{\circ} \mathrm{C}$ and $150{ }^{\circ} \mathrm{C}$ respectively.

\section{Results and discussion}

The studies presented in this paper have been performed to verify the applicability of the Headspace method in combination with GC-MS for identification VOC emitted from interior materials. Such tests could supplement indoor air studies. Examining the indoor air it can be stated only that there are emission sources in the room. But if the purpose of research is to improve air quality, it is necessary to identify the source of emission, i.e. to identify the VOC emitting material, to be able to remove the source of emission from the room. Testing of the method was made by determining the gas phase composition under 
various operating conditions of the headspace. The type and amount of emitted compounds was investigated according to temperature and the time of heating the samples. 30 minute sample healing was applied during the temperature studies, while the effects of time were investigated at 60 and $90^{\circ} \mathrm{C}$.

\subsection{Emission dependence from time and temperature}

For four of the tested materials (G, I, K and L), the area of chromatographic peaks increases with increasing temperature, i.e. the quantity and number of emitted compounds were increased over the whole temperature range. This is illustrated in Figure 3 and 4a. For the next four materials (A, B, C and J), the growth of the peak area is shown with increasing temperature, but only at a temperature of $90{ }^{\circ} \mathrm{C}$ (Fig. 4b). On the other hand, for samples of materials $\mathrm{H}, \mathrm{F}$ and $\mathrm{M}$, the emission levels in the range of $60-120{ }^{\circ} \mathrm{C}$ show slight fluctuations and the emission increase is observed only at $150{ }^{\circ} \mathrm{C}$ (Fig. 4c). While for the sample of mineral wool no significant increase in emissions was observed in the temperature range of $60-150^{\circ} \mathrm{C}$ (Fig. $\left.4 \mathrm{~d}\right)$.
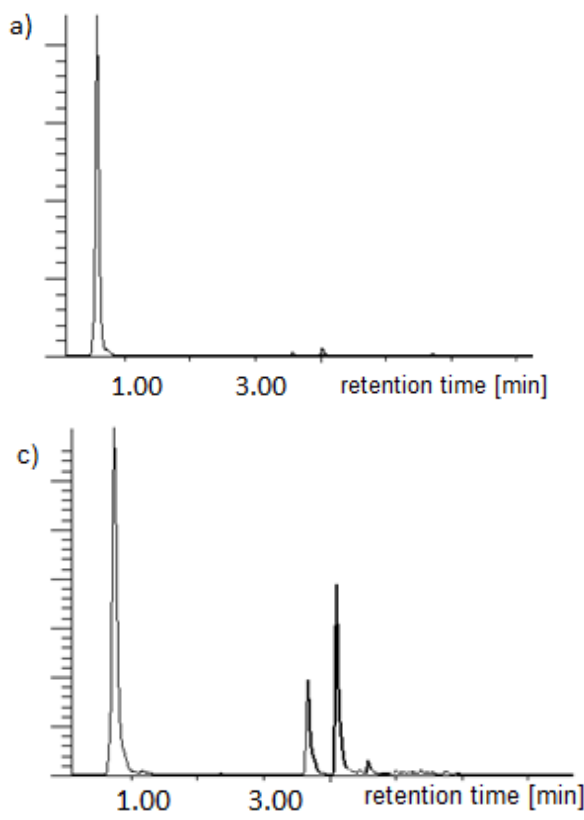

b)
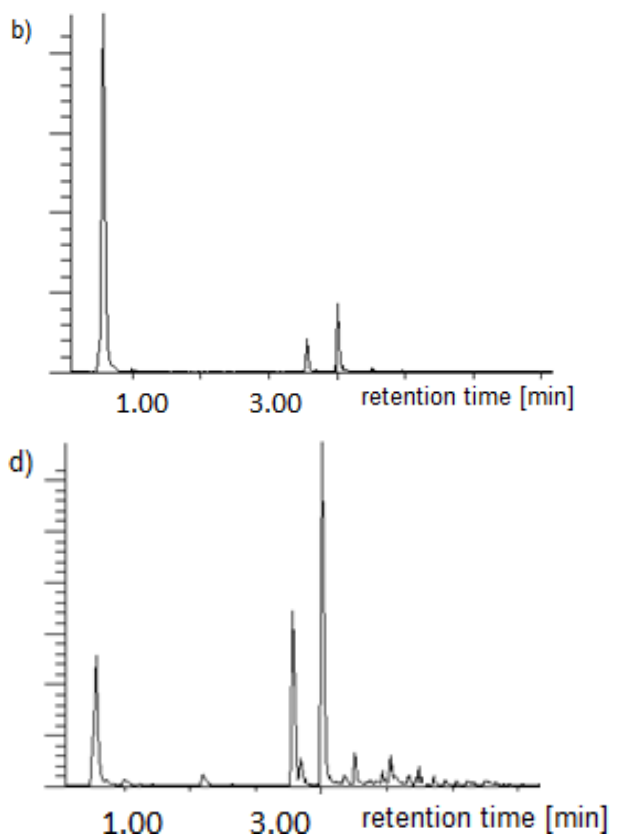

Fig. 3. Chromatograms for blue styrodur STYROFOAM XPS 300 heated at: a) $60{ }^{\circ} \mathrm{C}$, b) $90{ }^{\circ} \mathrm{C}$, c) $120^{\circ} \mathrm{C}$, d) $150{ }^{\circ} \mathrm{C}$.

In conclusion, it can be stated that it is difficult to indicate the preheating temperature of the sample which will be most optimal for all building materials. On the one hand, to simulate more real VOC emission conditions, low temperatures that are closest to room temperature should be used. The lowest temperature at which the samples were analysed was $60{ }^{\circ} \mathrm{C}$ because it was the temperature that allowed stable operation of the headspace. Raising the temperature increased the emission of organic compounds, for all materials except mineral wool. However, these are not the conditions that occur in buildings every day. 
a)

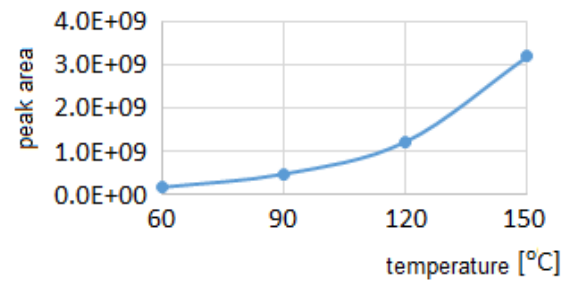

c)

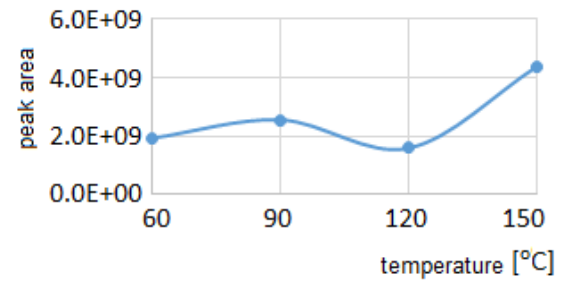

b)

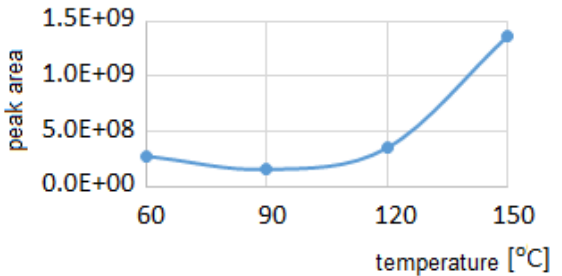

d)

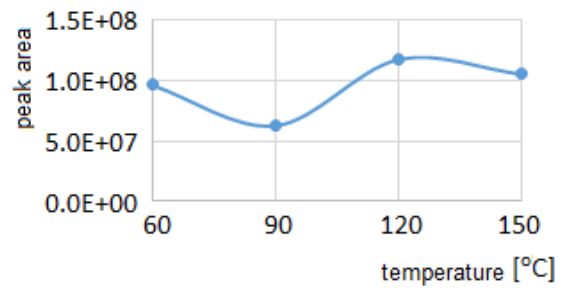

Fig. 4. Dependence of the total surface area of the peaks on the temperature for selected materials: a) perforated profile, b) corrugated PVC pipe, c) gray styrodur XPS, d) mineral wool.

Prolongation of the heating time from $30 \mathrm{~min}$ to $120 \mathrm{~min}$ does not cause significant changes in type and amount of emitted compounds. While 24-hour sample heating resulted in almost fourfold increase the peak area (Fig.5). The increase in the total surface area of the peaks is mainly due to the increase in the surface area of the peaks. Changes in the profile of released compounds are small. Probably during long-term heating VOCs are released to the gas phase from both the surface layer and also from inside of the material.

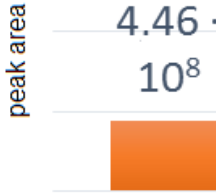

0.5

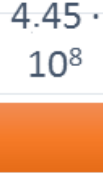

2

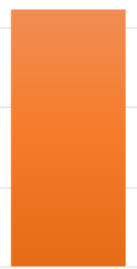

24 time [h]

Fig. 5. Dependence the total peak area on the heating time for styrofoam.

For most tested materials, 30-minute sample heating was sufficient to determine which compounds emitted the material. The longer time, i.e. 24 hours, is recommended only for low emission materials.

\subsection{Type of compounds emitted from tested materials}

The number of emitted compounds was very different for each material, from several for mineral wool or polyurethane foam to several dozen for perforated profile. Table 2 lists the groups of emitted compounds in the most abundant and in parentheses specific examples.

The most secure material among the selected for analysis was mineral wool due to the amount and type of emitted compounds. No emissions of aromatic hydrocarbons and formaldehyde from this material were recorded. The greatest risk to health due to the large number of emitted organic compounds potentially creates a corrugated tube. On the other 
hand, such materials as blue styrofoam (F) and fire-retardant polyurethane foam (E) may pose a risk due to the high participation of aromatic hydrocarbons.

Comparing the obtained results with literature reports $[2,10]$, the compatibility of the group of emitted compounds can be found, while there are differences in the emission of specific compounds. This partial accordance may result from testing one specific material and the fact that other substances may now be used in the production than it was a dozen or so years ago.

Table 2. List of the most common VOCs emitted from the tested materials. Indication of materials according to Table 1

\begin{tabular}{|c|c|}
\hline & $\begin{array}{l}\text { The most common VOCs emitted from the tested building and finishing } \\
\text { materials }\end{array}$ \\
\hline A & $\begin{array}{l}\text { alcohols (especially: 2-(2-ethoxyethoxy) ethanol), saturated aliphatic hydrocarbons, } \\
\text { carboxylic acid esters, ketones }\end{array}$ \\
\hline B & $\begin{array}{l}\text { aliphatic saturated hydrocarbons, alcohols (e.g. 2-(2-ethoxy-ethoxy)ethanol), } \\
\text { carboxylic acid esters (e.g. 1,2-benzene-dicarboxylic acid diethyl ester), amines, } \\
\text { ketones }\end{array}$ \\
\hline $\mathrm{C}$ & $\begin{array}{l}\text { aromatic hydrocarbons (especially: ethylbenzene, styrene, propenylbenzene, } \\
\text { propylbenzene, xylene), alcohols (among others: } 2 \text {-( } 2 \text {-ethoxyethoxy)ethanol), } \\
\text { aldehydes (among others: benzaldehyde), saturated aliphatic hydrocarbons } \\
\text { (especially: } 2 \text {-methylbutane) }\end{array}$ \\
\hline $\mathrm{D}$ & $\begin{array}{l}\text { alcohols (especially: 2-(2-ethoxyethoxy)ethanol, 2-[2-(2- } \\
\text { ethoxyethoxy)ethoxy]ethanol) }\end{array}$ \\
\hline $\mathrm{E}$ & $\begin{array}{l}\text { aromatic hydrocarbons, carboxylic acid esters, alcohol: 2-(2-butoxyethoxy)ethanol, } \\
\text { saturated aliphatic hydrocarbons }\end{array}$ \\
\hline $\mathrm{F}$ & $\begin{array}{l}\text { aromatic hydrocarbons (especially: xylene, ethylbenzene, styrene, saturated } \\
\text { aliphatic hydrocarbons (especially: } 2 \text {-methyl-propane), alcohols (e.g. 2-(2- } \\
\text { ethoxyethoxy)ethanol), aldehydes (e.g. benzaldehyde) }\end{array}$ \\
\hline G & $\begin{array}{l}\text { alcohols (especially: 2-(2-ethoxyethoxy)ethanol), amines, ketones, aliphatic } \\
\text { hydrocarbons (especially: 2,2,4,6,6-penta-methylheptane), aldehydes }\end{array}$ \\
\hline $\mathrm{H}$ & alcohols, saturated aliphatic hydrocarbons, ketones, aldehydes, amines \\
\hline I & $\begin{array}{l}\text { alcohols (especially: 2-(2-ethoxyethoxy)ethanol, 2-(2-butoxyethoxy)ethanol), } \\
\text { carboxylic acid esters (especially: butanoic acid butyl ester), amines, aldehydes } \\
\text { (especially: benzaldehyde), acids (e.g. acetic acid) }\end{array}$ \\
\hline $\mathrm{J}$ & $\begin{array}{l}\text { alcohols (especially: 2-(2-butoxyethoxy)ethanol, 2-(2-ethoxyethoxy)ethanol), } \\
\text { carboxylic acid esters (especially: butanoic acid butyl ester), ketones, aldehydes }\end{array}$ \\
\hline K & $\begin{array}{l}\text { alcohols (especially: } 2 \text {-(2-ethoxyethoxy)ethanol), carboxylic acid esters (especially: } \\
\text { butanoic acid butyl ester), amines, ketones, saturated aliphatic hydrocarbons }\end{array}$ \\
\hline $\mathrm{L}$ & $\begin{array}{l}\text { aliphatic saturated hydrocarbons (e.g. 2,2,4,6,6-pentamethyl-heptane), carboxylic } \\
\text { acid esters, alcohols (especially: 2-(2-ethoxyethoxy)ethanol), aromatic } \\
\text { hydrocarbons (especially: xylene, ethylbenzene), ketones, amines, amides }\end{array}$ \\
\hline M & $\begin{array}{l}\text { aromatic hydrocarbons (especially: ethylbenzene, styrene, propylbenzene), } \\
\text { saturated aliphatic hydrocarbons, aldehydes (especially: benzaldehyde) }\end{array}$ \\
\hline
\end{tabular}




\section{Conclusion}

Headspace method, in combination with gas chromatography and mass spectrometry enables the identification of organic compounds emitted from finishing and building materials. Such tests may be complementary to indoor air quality research that identify VOC emission sources.

It is important to determine the optimum working conditions for the tested materials. By heating the sample at a lower temperature, you can simulate measurement conditions that are close to the real conditions of use the tested materials. The increase in sample temperature results in an increase in the type and amount of identified compounds for most tested materials. But the sensitivity of the method can also be increased by prolongation the time of heating the sample.

\section{References}

1. A.P. Jones, Atmos. Environ. 33, 4535 (1999)

2. B. Zabiegała, Pol. J. Environ. Stud. 15, 383 (2006)

3. Organic Indoor Air Pollutants: Occurrence, Measurement, Evaluation (Wiley Online Library, 2009)

4. Indoor air quality \& its impact on man, EC Raport No.19 (Luxembourg, 1997)

5. A. Colombo, M. De Bortoli, E. Pecchio, H. Schauenburg, H. Schlitt, H. Vissers, Sci. Total Environ. 91, 237 (1990)

6. A. Niesłochowski, Izolacje 1/2011, 40 (2011)

7. I. Pecka, R. Wilglusz, E. Sitko, G. Nikiel, Roczn. PZH 55, 181 (2004)

8. J.M. Hugo, M.W. Spence, T.D. Lickly. Appl. Occup. Environ. Hyg. 15, 512 (2000)

9. T.J. Kelly, J.D. Myers, M.W. Holdren, Indoor Air 9, 117 (1999)

10. A. Niesłochowski, Prace ITB 165, 9 (2013)

11. C. Rodríguez-Navas, R. Forteza, V. Cerdà, Chemosphere 89, 1426 (2012)

12. B. Kolb, L.S. Ettre, Static Headspace-Gas Chromatography: Theory and Practice (Wiley, 2006)

13. N.H. Snow, G.C. Slack, Trends Analyt. Chem. 21, 608 (2002)

14. N.H. Snow, G.P. Bullock, J. Chromatogr. A 1217, 2726 (2010)

15. J.C. Flórez Menéndez, M.L. Fernández Sánchez, J.E. Sánchez Uría, E. Fernández Martínez, A. Sanz-Medel, Anal. Chim. Acta 4159 (2000)

16. C. Ubeda, R.M. Callejón, C. Hidalgo, M.J. Torija, A. Mas, A.M. Troncoso, M.L. Morales, Food Res. Int. 44, 259 (2011)

17. M. Półka, P. Sulik, Zeszyty Naukowe SGSP 40, 99 (2010)

18. W. Śmiszek-Lindert, A. Bajorek, J. Kubacki, Chemik 69, 411 (2015) 